\title{
MENINGKATKAN KEMAMPUAN BERBICARA ANAK USIA DINI MELALUI METODE BERCERITA MENGGUNAKAN MEDIA HASIL KARYA ANAK
}

\author{
Ria Faridawati, Cucu Eliyawati, Rudiyanto \\ Universitas Pendidikan Indonesia, Jln. Setiabudhi no. 229 Bandung \\ e-mail: riafarida.fw@gmail.com
}

\begin{abstract}
Abstrack : Increase Speaking Skills In Early Childhood Through Story Method Using Children's Works Media. Based on the background and the reality in the scope shows that the children's speaking skills are less, it seen when the time of learning activities there are children who have not clearly in pronouncing sentence, the child tend to be passive, quiet, less communicative, less responsive and less clear in conveying the message. It caused by incorrect use of the method of learning which given by the teacher in the classroom. Therefore, story methods using children's works media activities can be used as an alternative to make learning more meaningful. The purpose of this research is to improve the speaking skills of a group in Raudhatul Athfal Daarul Amanah with a learning story method using children's works media activities. This research method used classroom action research. Objects of this class action research is student a group in Raudhatul Athfal Daarul Amanah totaling 15 children, consisting of 8 girls and 7 boys. Based on the analysis of data after the research is done, the children's speaking skill was increase in each cycle, it seen starting from the first cycle that some of the child begins to dare to express his opinion in although it always have to be accompanied by a teacher, next on the second cycle that part of the child has started to express his opinion without bring accompanied by a teacher, next result on the third cycle, almost all children to express his opinion with confident, more communicative with many questions as well as able to speak fluently when the telling of his work. Therefore, it can be concluded that the through story method using children's work media activities can improve children's speaking skills in A group of Raudhatul Athfal Daarul Amanah Cimahi Academic Year 2015/2016.
\end{abstract}

Keywords : speaking, story method, children's work media.

\begin{abstract}
Abstrak : Meningkatkan Kemampuan Berbicara Anak Usia Dini Melalui Metode Bercerita Menggunakan Hasil Karya Anak. Berdasarkan latar belakang serta realita yang ada di lapangan menunjukkan bahwa kemampuan berbicara anak masih kurang, terlihat pada saat kegiatan pembelajaran masih ada anak yang belum terlihat jelas dalam mengucapkan kalimat, anak cenderung pasif, pendiam, kurang komunikatif, kurang tanggap dan kurang jelas dalam menyampaikan pesan. Permasalahan tersebut salah satunya diakibatkan oleh belum tepatnya penggunaan metode pembelajaran dan media yang diberikan oleh guru di dalam kelas. Untuk itu, metode bercerita menggunakan media hasil karya anak dapat dijadikan alternatif untuk menjadikan pembelajaran lebih bermakna. Tujuan penelitian ini adalah untuk meningkatkan kemampuan berbicara anak pada kelompok A di Raudhatul Athfal Daarul Amanah melalui metode bercerita menggunakan media hasil karya anak. Metode penelitian ini menggunakan penelitian tindakan kelas. Obyek penelitian tindakan kelas ini adalah siswa kelompok A Raudhatul Athfal Daarul Amanah yang berjumlah 15 anak diantaranya 8 anak perempuan dan 7 anak laki-laki. Berdasarkan hasil analisis data yang telah dilakukan, kemampuan berbicara anak mengalami peningkatan pada setiap
\end{abstract}


siklusnya, dimulai pada siklus I dimana beberapa anak mulai berani mengungkapkan pendapatnya meskipun harus selalu ditemani oleh guru, dilanjutkan pada siklus II dimana sebagian anak mulai berani mengungkapkan pendapatnya tanpa ditemani oleh guru, selanjutnya pada siklus III dengan hasil hampir seluruh anak berani mengungkapkan pendapatnya dengan percaya diri, lebih komunikatif dengan banyak bertanya serta mampu berbicara dengan lancar ketika menceritakan hasil karyanya. Oleh karena itu, dapat disimpulkan bahwa pembelajaran melalui metode bercerita menggunakan media hasil karya anak dapat meningkatkan kemampuan berbicara anak pada kelompok A di Raudhatul Athfal Daarul Amanah Cimahi Tahun Ajaran 2015/2016.

Kata Kunci : berbicara, metode bercerita, hasil karya anak.

Kemampuan dalam berbicara merupakan kebutuhan yang sangat penting bagi seseorang agar dapat berkomunikasi dengan orang lain secara lisan didalam kehidupan sehari-hari. Kemampuan berbicara perlu dipelajari dengan latihan serta pembiasaan secara terus-menerus agar berkembang sesuai dengan yang diharapkan. Hurlock (1991, hlm. 185) menyatakan tiga tugas utama pembelajaran kemampuan berbicara, dimana ketiga proses tersebut terpisah namun saling berhubungan antara satu dan yang lainnya, yakni "pengucapan, pengembangan kosakata dan pembentukan kalimat, ketiga proses tersebut saling berkaitan sehingga apabila gagal menguasai salah satunya akan membahayakan keseluruhan pola berbicara".

Berdasarkan hasil observasi yang peneliti lakukan di Raudhatul Athfal Daarul Amanah, diketahui bahwa kemampuan berbicara anak pada kelompok A masih terbilang rendah. Dapat dilihat pada tahap pengucapan, dimana terdapat beberapa anak yang belum mampu meniru, menyebutkan nama benda, kata sifat yang disampaikan oleh guru hal ini tergambar dengan perilaku anak yang hanya bisa melontarkan senyum dan tersipu malu, menggelengkan kepala atau hanya menjawab "tidak tahu!". Sementara itu pada tahap pengembangan kosakata, belum beraninya anak bertanya atau menanggapi tentang sesuatu hal yang disampaikan guru, hal ini terlihat pada perilaku anak yang terlihat takut atau menghindar ketika guru bertanya. Selanjutnya pada tahap pembentukan kalimat terdapat anak yang hanya bisa terdiam ketika diajak bercakap-cakap atau diberi perintah sederhana oleh guru, dan hampir sebagian anak belum mampu memberikan pendapat atau informasi tentang sesuatu hal yang ia ketahui terlihat anak tidak begitu antusias untuk berbicara atau mengungkapkan ide ataupun perasaannya. Permasalahan tersebut salah satunya diakibatkan oleh belum tepatnya penggunaan metode pembelajaran dan media yang diberikan oleh guru di dalam kelas sehingga pembelajaran kurang bermakna.

Metode bercerita merupakan salah satu metode yang sering digunakan untuk meningkatkan kemampuan berbicara pada anak. Anak usia 3-4 tahun sudah gemar bercerita, apabila anak dilibatkan dalam kegiatan bercerita maka akan tercipta pembelajaran yang aktif dimana anak sebagai sumber belajarnya. Hal ini selaras dengan pendapat Gunarti (2008, hlm. 53) yaitu "seorang anak yang berada pada rentang usia 3 sampai 4 tahun mulai menyukai tuturan cerita atau ia sendiri mulai senang untuk menuturkan cerita". Bercerita memerlukan alat bantu atau media untuk memudahkan seseorang dalam menyampaikan pesan. Hasil karya dapat 
dijadikan salah satu media untuk menyampaikan pesan karena mudah dibuat dan mendorong anak untuk belajar dengan aktif. Aktifitas berkarya sendiri sangat beragam menurut Rachmawati dan Kurniati (2010, hlm. 53) mengungkapkan bahwa "pada dasarnya hasil karya anak dibuat melalui aktivitas membuat, menyusun atau mengkonstruksi yang akan memberikan kesempatan bagi anak untuk menciptakan benda buatan mereka sendiri yang belum pernah mereka temui, ataupun mereka membuat modifikasi dari benda yang telah ada sebelumnya".

Dengan demikian metode bercerita menggunakan media hasil karya anak merupakan alat bantu saluran komunikasi yang berfungsi untuk menyampaikan pesan kepada orang lain melalui sebuah karya atau sesuatu yang dibuat, diciptakan dan dihasilkan oleh anak. Konsep hasil karya dalam penelitian ini lebih menitikberatkan pada membentuk sebuah karya yang kongkrit yang bisa ditangkap mata dan dirasakan dengan rabaan, salah satunya seperti; menggambar, membuat berbagai macam bentuk dari kepingan geometri, kolase dll. Mengingat karakteristik anak usia dini yang masih membutuhkan benda konkrit untuk memahami konsep yang abstrak, hasil karya anak sangatlah cocok digunakan sebagai salah satu upaya alternatif untuk meningkatkan kemampuan berbicara.

Tujuan penelitian ini adalah untuk meningkatkan kemampuan berbicara melalui metode bercerita menggunakan media hasil karya pada anak kelompok A Raudhatul Athfal Daarul Amanah tahun ajaran 2015/2016.

\section{METODE}

Penelitian ini dilaksanakan di Raudhatul Athfal Daarul Amanah yang berlokasi di Kota Cimahi tahun ajaran 2015/2016. Subjek penelitian ini adalah siswa kelompok A Raudhatul Athfal Daarul Amanah yang berjumlah 15 anak diantaranya 8 anak perempuan dan 7 anak laki-laki. Metode yang dikembangkan pada penelitian ini adalah dengan menggunakan metode penelitian tindakan kelas. Penelitian dilaksanakan dalam III siklus, setiap siklus terdiri dari empat tahapan yaiu perencanaan, pelaksanaan, pengamatan dan refleksi. Teknik pengumpulan data yang digunakan adalah pengamatan (observasi), wawancara, dan studi dokumentasi. Sedangkan Validasi data dalam penelitian ini dilakukan dengan pengecekan kembali data atau pemeriksaan ulang data yang lebih dikenal dengan triangulasi yang terdiri dari triangulasi sumber, triangulasi metode dan triangulasi waktu. Kemudian seluruh data yang telah dikategorikan validasinya yang meliputi hasil pengamatan, wawancara, dan studi dokumentasi dianalisis dan diinterpretasikan secara deskriptif kualitatif.

\section{HASIL DAN PEMBAHASAN}

Berdasarkan hasil wawancara yang dilakukan pada guru kelas dan data kemampuan berbicara yang diperoleh dari hasil pengamatan menggunakan pedoman observasi yang disesuaikan berdasarkan tugas utama dalam berbicara menurut Hurlock (1991, hlm. 185) Terdiri dari pengucapan, pengembangan kosakata, dan pembentukan kalimat dengan indikator aspek kemampuan berbicara anak usia 4-5 tahun berdasarkan Permendikas No. 58 Tahun 2009 diketahui bahwa pada kondisi awal tingkat kemampuan berbicara anak kelompok A Raudhatul Athfal Daarul Amanah sebelum dilakukan tindakan pada 
umumnya masih berada pada kategori kurang berkembang. dengan persentase 45,33\% pada kategori Kurang (K), kategori cukup (C) sebanyak 24\% dan kategori Baik (B) hanya 30,67\%. Hal ini juga dapat dilihat dengan belum jelasnya anak dalam meniru kata, mengucapkan kalimat, anak terlihat kesulitan dalam menyusun kalimat sederhana dengan struktur yang lengkap, kurang tanggap dan kurang jelas dalam menyampaikan ide atau pesan, anak cenderung pasif, pendiam dan kurang komunikatif.

Melihat kondisi objektif kemampuan berbicara anak serta berbagai masalah yang telah dijabarkan sebelumnya, maka peneliti dan guru berkolaborasi untuk memecahkan masalah dalam memperbaiki kondisi yang dihadapi anak didik, selanjutnya peneliti dan guru menemukan solusi yang diharapkan akan memperbaiki keadaan kemampuan berbicara anak yakni pembeajaran melalui metode bercerita menggunakan media hasil karya anak. Mengingat metode yang sering digunakan salah satunya adalah metode bercerita maka dari itu peneliti dan guru sepakat untuk menggunakan metode bercerita dalam pembelajaran untuk meningkatkan kemampuan berbicara, namun metode bercerita yang akan dilakukan berbeda dengan metode bercerita yang biasa digunakan sebelumnya dimana guru yang berbicara aktif "teacher center" dan anak hanya menjadi pendengar setia. Pada pembelajaran yang akan dilakukan selanjutnya adalah anak yang akan belajar secara aktif "student center" dengan tipe demokratis dimana anak dapat membuat hasil karya dan menceritakan hasil karyanya.

Dimulai pada siklus I dimana anak membuat sebuah karya dengan menggambar diri sendiri kemudian menceritakan karyanya tersebut di hadapan temannya. Berdasarkan penelitian yang telah dilakukan pada siklus I diketahui bahwa kemampuan berbicara anak sedikit mengalami peningkatan ke arah yang lebih baik, terlihat pada kategori Baik (B) sebanyak 34,7\%, kategori Cukup (C) sebanyak 28,6\% dan kategori Kurang (K) menyusut menjadi $36,7 \%$. Dapat dilihat bahwasannya respon anak cukup baik, beberapa anak sudah mulai menunjukan keberaniannya menceritakan karyanya meskipun harus selalu diberi motivasi. Namun terlihat masih banyak anak yang belum mampu atau merasa kebingungan menceritakan hasil karya yang dibuatnya. Ada anak yang terlihat takut tampil dihadapan temannya sehingga anak hanya bisa diam sejenak ada pula yang masih malu-malu dengan mengeluarkan suara yang sangat pelan sehingga tidak terdengar oleh teman yang lain. Hal ini menunjukan bahwa peneliti harus melakukan perbaikan pada siklus selanjutnya agar tercapai tujuan yang diharapkan.

Dilanjukan pada siklus ke II dimana anak membuat karya dengan membuat berbagai bentuk dari kepingan geometri kemudian menceritakan karyanya tersebut di hadapan temannya. Pada siklus II sebagian anak mengalami peningkatan kemampuan berbicara yang baik dimana kemampuan berbicara anak pada kategori Baik (B) sebanyak 50,7\%, kategori Cukup (C) meningkat sebanyak $28,7 \%$ dan kategori kurang menyusut menjadi 20,6\%. Dapat dilihat pula bahwasannya semua anak sudah terlihat antusias mengikuti pembelajaran, selain itu, sebagian besar anak sudah cukup berani untuk tampil dihadapan temannya untuk menceritakan hasil karyanya walaupun dengan suara yang sangat pelan sehingga tidak terdengar oleh teman yang lain dan harus selalu di bimbing oleh guru untuk dapat mengungkapkan ide/ pendapatnya. Hal ini menunjukan bahwa 
pelaksanaan tindakan pada siklus II sudah berjalan dengan baik namun masih perlu dilakukan lagi tindakan pada siklus berikutnya agar mendapatkan hasil yang maksimal. Karena pada siklus II belum mencapai indikator kinerja yang ditentukan yaitu sebesar 75\%, maka penelitian dilanjutkan pada siklus III.

Pada siklus III anak membuat kolase kemudian menceritakan karyanya tersebut di hadapan temannya. Pada siklus III ini hampir seluruh anak berani mengungkapkan pendapatnya dengan percaya diri, lebih komunikatif dengan banyaknya bertanya, mampu berbicara dengan lancar ketika menceritakan hasil karyanya, serta mampu menanggapi dan mengungkapkan idenya. Hal ini menunjukan bahwa tindakan yang telah dilakukan serta perbaikan dari siklus sebelumnya telah berhasil meningkatkan kemampuan berbicara pada anak kelompok A Raudhatul Athfal Daarul Amanah dengan sangat baik, terlihat hampir seluruh anak pada siklus III berada pada kategori Baik (B) dengan mencapai persentase 75,34\% melebihi kriteria yang telah ditetapkan yakni 75\%, sementara kategori Cukup (C) sebanyak 13,33 \%, sedangkan anak yang berada pada kategori Kurang (K) menyusut menjadi 11,33\%.

Berdasarkan hasil pengamatan dan evaluasi Siklus III terhadap pembelajaran melalui metode bercerita mengunakan media hasil karya anak untuk meningkatkan kemampuan berbicara anak kelompok A Raudhatul Athfal Daarul Amanah, telah terlaksana sesuai dengan rencana dan menunjukkan peningkatan yang cukup signifikan dan cukup optimal, Maka dari itu secara umum siklus III ini dapat dihentikan dan dijadikan sebagai siklus terakhir dalam penelitian ini.

\section{SIMPULAN}

Kemampuan berbicara anak kelompok A Raudhatul Athfal Daarul Amanah setelah diberi tindakan melalui metode bercerita menggunakan media hasil karya anak mengalami peningkatan pada setiap siklusnya. Dimana pada tahap observasi awal kemampuan berbicara anak pada umumnya berada pada kategori kurang berkembang terlihat pada saat kegiatan pembelajaran hampir sebagian anak belum jelas dalam meniru kata, kesulitan dalam menyusun kalimat sederhana dengan struktur yang lengkap, kurang jelas dalam menyampaikan pesan, anak cenderung pasif dan pendiam. Setelah dilakukannya tindakan melalui tiga siklus pembelajaran, kemampuan berbicara anak semakin mengalami peningkatan. Hal ini terlihat sudah mampunya anak meniru dan menyebutkan kata dengan lebih baik, anak sudah mampu mengemukakan pendapatnya dengan percaya diri, lebih komunikatif dengan banyak bertanya, dan mampu menceritakan hasil karya yang dibuatnya sendiri dihadapan temannya. Dengan demikian dapat disimpulkan bahwa pembelajaran melalui metode bercerita menggunakan media hasil karya anak dapat meningkatkan kemampuan berbicara pada anak kelompok A Raudhatul Ahfal Daarul Amanah Cimahi Tahun Ajaran 2015/2016.

\section{DAFTAR PUSTAKA}

Gunarti, Winda. (2008). Metode Pengembangan Perilaku dan Kemampuan Dasar Anak Usia Dini. Universitas Terbuka: Jakarta.

Hurlock, Elizabeth. B. (1991). Psikologi Perkembangan: Sepanjang Rentang Kehidupan. Jakarta: Erlangga. Rachmawati, Yeni dan Kurniati, Euis. (2010). Strategi Pengembangan 
Kreativitas Anak Usia Taman Kanakkanak. Jakarta: Kencana

Peraturan Pemerintah Pendidikan Nasional No 58 Tahun 2009. 